\title{
Gamma Radiation Hazards and Risks Associated with Industrial Wastes Materials
}

\author{
Jamilah Al-Zahrani \\ Physics Department, Girls Faculty of Science, King Abdulaziz University, Jeddah, KSA \\ Email: Jalzhrani@kau.edu.sa
}

How to cite this paper: Al-Zahrani, J. (2017) Gamma Radiation Hazards and Risks Associated with Industrial Wastes Materials. Journal of Geoscience and Environment Protection, 5, 24-30. https://doi.org/10.4236/gep.2017.54003

Received: March 6, 2017

Accepted: April 16, 2017

Published: April 19, 2017

Copyright (C) 2017 by author and Scientific Research Publishing Inc. This work is licensed under the Creative Commons Attribution International License (CC BY 4.0).

http://creativecommons.org/licenses/by/4.0/

(c) (†) Open Access

\begin{abstract}
Solid wastes are generated from common manufacturing and industrial processes, and can also be caused by disposing commerce products. The natural radionuclide $\left({ }^{238} \mathrm{U},{ }^{226} \mathrm{Ra},{ }^{232} \mathrm{Th}\right.$ and $\left.{ }^{40} \mathrm{~K}\right)$ concentrations in various solid waste samples were determined by using a high pure germanium detector. The obtained average concentration values of ${ }^{226} \mathrm{Ra},{ }^{232} \mathrm{Th}$, and ${ }^{40} \mathrm{~K}$ in various solid wastes were: Iron $\left(173.29,141.99\right.$ and $\left.32.68 \mathrm{~Bq} \cdot \mathrm{kg}^{-1}\right)$, Copper $(2.63,0.60$ and $\left.30 \mathrm{~Bq} \cdot \mathrm{kg}^{-1}\right)$, Aluminum (3.97, 4.89 and $\left.41.67 \mathrm{~Bq} \cdot \mathrm{kg}^{-1}\right)$ and in Wood $(4.22,3.11$ and $\left.30.20 \mathrm{~Bq} \cdot \mathrm{Kg}^{-1}\right)$, respectively. The total average values of radium equivalent and the absorbed dose rate were $95.87 \mathrm{~Bq} \cdot \mathrm{kg}^{-1}$ and $44.56 \mathrm{nGyh}^{-1}$, respectively. The effective dose rates in outdoor and indoor average values were 0.05 and $0.20 \mathrm{mSvy}^{-1}$, respectively. These health hazard parameters were considered to be below the safe limit of UNSCEAR 2000. The presented results show no significant radiological health risks for the workers in the industrial workshops and inhabitance health.
\end{abstract}

\section{Keywords}

Gamma Ray spectrometry, Waste, Effective Dose, Risk

\section{Introduction}

"The occurrence of natural radionuclides ${ }^{226} \mathrm{Ra},{ }^{232} \mathrm{Th}$ and ${ }^{40} \mathrm{~K}$ in industrial solid waste is the source of the radiation hazard to the population and the environment [1]". Monitoring all sources of natural radiation in the workplace is essential to evaluate the potential environmental risk [2]. Some industrial activities produce a huge amount of wastes which might pollute the environment. In fact, "Industrial waste is the fastest growing materials which lead to doses of radiation exposure. If this waste is not organized and recycled, no areas will be available to store it [3]". The industrial solid waste product of Iron, Aluminium, Cooper and 
wood could be found as sharp pieces or as a powder. These products are formed either by filling the metals and woods, or by mending finished materials, or by several other methods, including automatic and manual ones. These waste materials may be the source of natural radiation for the workers at the workshops. In general, there is no control over the operation of these industrial workshops, and there is no specific approach to a guideline of natural radioactivity of industrial wastes. Thus, the first aim of this work is the measurement of the natural radionuclides $\left({ }^{226} \mathrm{Ra},{ }^{232} \mathrm{Th}\right.$ and $\left.{ }^{40} \mathrm{~K}\right)$ in different samples of industrial solid wastes (Iron, Aluminium, Copper and wood). The second aim is the assessment of the radiological hazard to the environment and the workers at the workshops that produce materials with enhanced content of natural nuclides. The significance of this study is to supply basic safety standards for the sake of workers and public health against the danger arising from such industrial waste.

\section{Materials and Methods}

Twenty-five of solid waste samples were collected from several Industrial workshops in Saudi Arabia, Jeddah city. The collected samples were oven dried at $110^{\circ} \mathrm{C}$ for twelve hours and then packed in a Marinelli beaker and sealed for one month to reach secular equilibrium between ${ }^{226} \mathrm{Ra}$ and ${ }^{232} \mathrm{Th}$ with their decay products. The radionuclide activity concentrations in the prepared samples were measured using a high-purity germanium (HPGe) detector with an efficiency of about $25 \%$. A counting time of 36,000 s was used for measurements the Gamma-rays spectrum. The background concentration of the $\gamma$-rays was determined with an empty Marinelli beaker under the same measurement conditions. ${ }^{226} \mathrm{Ra}$ activities were calculated from the activities of its short-lived daughters ${ }^{214} \mathrm{~Pb}$ at $295.2 \mathrm{keV} \& 351.9 \mathrm{keV}$ and ${ }^{214} \mathrm{Bi}$ at $609.3 \mathrm{keV}$. ${ }^{232} \mathrm{Th}$ activities were measured by taking the mean activity of photo peaks of the daughter nuclides ${ }^{228} \mathrm{Ac}(338.40$ and $911.07 \mathrm{keV})$ and ${ }^{212} \mathrm{~Pb}(238.63 \mathrm{keV})$. Activities of ${ }^{40} \mathrm{~K}$ were determined directly from its gamma emission at $1460.83 \mathrm{keV}$.

The activity concentrations of the investigated samples were evaluated using the following equation [4] [5]:

$$
\operatorname{Ac}(\mathrm{Bq} / \mathrm{kg})=\mathrm{Nc} / \varepsilon \beta \mathrm{M}
$$

where $\mathrm{Nc}$ is the net gamma counting rate (counts per second), $\varepsilon$ the detector efficiency of the specific $\gamma$-ray, $\beta$ the absolute transition probability of Gammadecay and $\mathrm{M}$ the mass of the sample $(\mathrm{kg})$.

\section{Assessment of Radiation Hazard}

\subsection{Radium Equivalent Activity ( $\left.\mathbf{R}_{\mathrm{eq}}\right)$}

To assess the radiological hazard of the concerning samples, it is useful to use the radium equivalent activity $\left(\mathrm{R}_{\mathrm{eq}}\right)$ in $\mathrm{Bq} \cdot \mathrm{Kg}^{-1}[5]$ :

$$
\mathrm{R}_{\text {eq }}=\mathrm{A}_{\mathrm{Ra}}+1.43 \mathrm{~A}_{\mathrm{Th}}+0.077 \mathrm{~A}_{\mathrm{K}}
$$

where $A_{T h}, A_{R a}$ and $A_{K}$ represent the activity concentrations of ${ }^{232} \mathrm{Th},{ }^{226} \mathrm{Ra}$ and 
${ }^{40} \mathrm{~K}$ in $\mathrm{Bq} \cdot \mathrm{kg}^{-1}$ respectively. $\mathrm{R}_{\mathrm{eq}}$ is defined according to the estimation that 1 $\mathrm{Bq} \cdot \mathrm{kg}^{-1}$ of ${ }^{226} \mathrm{Ra}, 0.7 \mathrm{~Bq} \cdot \mathrm{kg}^{-1}$ of ${ }^{232} \mathrm{Th}$ and $13 \mathrm{~Bq} \cdot \mathrm{kg}^{-1}$ of ${ }^{40} \mathrm{~K}$ produce the same gamma-ray dose [6] the permissible dose limit for the public is $1.5 \mathrm{mSvy}^{-1}$ [7].

\subsection{Absorbed Gamma Dose Rate (D)}

The absorbed gamma dose scale in air 1mabove the ground surface for the uniform distribution of radionuclides $\left({ }^{232} \mathrm{Th},{ }^{238} \mathrm{U}\right.$, and $\left.{ }^{40} \mathrm{~K}\right)$ were computed by guidelines provided by [5]:

$$
\mathrm{D}\left(\mathrm{nGy} \cdot \mathrm{h}^{-1}\right)=\left(0.621 \mathrm{~A}_{\mathrm{Th}}+0.462 \mathrm{~A}_{\mathrm{Ra}}+0.0417 \mathrm{~A}_{\mathrm{K}}\right)
$$

where $A_{T h}, A_{R a}$ and $A_{K}$ represent the activity concentrations of ${ }^{232} \mathrm{Th},{ }^{226} \mathrm{Ra}$ and ${ }^{40} \mathrm{~K}$ in $\mathrm{Bq} \cdot \mathrm{Kg}^{-1}$ respectively.

\subsection{The Annual Effective Dose Equivalent ( $D_{\text {eff }}$ )}

The annual effective dose equivalent received by a member has been calculated from the absorbed dose rate by applying dose conversion factor of $0.7 \mathrm{~Sv} / \mathrm{Gy}$ and the occupancy factor for outdoor and indoor as 0.2 and 0.8 , respectively, [5], using the following equations:

$$
\begin{gathered}
\mathrm{D}_{\text {eff }}(\text { Outdoor })(\mathrm{mSv} / \mathrm{y})=\mathrm{D}\left(\mathrm{nGy} \cdot \mathrm{h}^{-1}\right) \times 7320 \mathrm{~h} \times 0.7 \mathrm{~Sv} / \mathrm{Gy} \times 0.2 \times 10^{-6} \\
\mathrm{D}_{\text {eff }}(\text { Indoor })(\mathrm{mSv} / \mathrm{y})=\mathrm{D}\left(\mathrm{nGy} \cdot \mathrm{h}^{-1}\right) \times 7320 \mathrm{~h} \times 0.7 \mathrm{~Sv} / \mathrm{Gy} \times 0.8 \times 10^{-6} .
\end{gathered}
$$

\subsection{Excess Lifetime Cancer Risk (ELCR)}

Excess Lifetime Cancer Risk (ELCR) was calculated by the equation below [4] [5]:

$$
\text { ELCR }=\text { Deff }(\text { outdoor }) \times D_{L} \times R F
$$

where $D_{\text {eff }}$ (outdoor), $D_{L}$ and RF are the outdoor annual effective dose equivalent, the duration of life (70 years) and the risk factor $\left(\mathrm{Sv}^{-1}\right)$, fatal cancer risk per Sievert. For detriment-adjusted cancer risk of $5.52 \times 10^{-2} \mathrm{~Sv}^{-1}$ for the whole population [5].

\section{Results and Discussion}

\subsection{Activity Concentration}

The results of ${ }^{226} \mathrm{Ra},{ }^{232} \mathrm{Th}$ and ${ }^{40} \mathrm{~K}$ concentrations in the waste samples were summarized in Table 1. From this Table, All samples under investigation, the average values of ${ }^{226} \mathrm{Ra}$ ranged from $2.6329 \mathrm{~Bq} \cdot \mathrm{Kg}^{-1}$ in (Copper) to 173.29 $\mathrm{Bq} \cdot \mathrm{Kg}^{-1}$ in (Iron). ${ }^{232} \mathrm{Th}$ average values ranged from $0.60 \mathrm{~Bq} \cdot \mathrm{Kg}^{-1}$ in (Copper) to $141.99 \mathrm{~Bq} \cdot \mathrm{Kg}^{-1}$ in (Iron) while the average values of ${ }^{40} \mathrm{~K}$ ranged from 29.99 $\mathrm{Bq} \cdot \mathrm{Kg}^{-1}$ in (Copper) to $41.99 \mathrm{~Bq} \cdot \mathrm{Kg}^{-1}$ in (Aluminum). Iron waste recorded the highest average values concentration of ${ }^{226} \mathrm{Ra}$ and ${ }^{232} \mathrm{Th}$, and are much higher than the world average values $30,35 \mathrm{~Bq} \cdot \mathrm{Kg}^{-1}$ for ${ }^{226} \mathrm{Ra}$ and ${ }^{232} \mathrm{Th}$ respectively, as reported by [5], which can be explained by adsorption on weathered ferromagnetic 
Table 1. Results of natural radioactivity concentration $\left(\mathrm{Bq} \cdot \mathrm{kg}^{-1}\right)$ in the waste samples collected from different industrial workshops, Saudi Arabia.

\begin{tabular}{|c|c|c|c|c|}
\hline \multirow{2}{*}{ Sample type } & \multirow{2}{*}{ Sample code } & \multicolumn{3}{|c|}{ Radioactivity concentration $\left(\mathrm{Bq} / \mathrm{kg}^{-1}\right)$} \\
\hline & & ${ }^{226} \mathrm{Ra}$ & ${ }^{232} \mathrm{Th}$ & ${ }^{40} \mathrm{~K}$ \\
\hline \multirow{5}{*}{ Iron } & $\mathrm{F} 1$ & $154.04 \pm 4.89$ & $162.28 \pm 2.27$ & $36.51 \pm 2.17$ \\
\hline & $\mathrm{F} 2$ & $171.34 \pm 5.12$ & $135.63 \pm 2.11$ & $35.69 \pm 2.0$ \\
\hline & F3 & $224.53 \pm 7.0$ & $164.63 \pm 2.22$ & $46.29 \pm 3.21$ \\
\hline & $\mathrm{F} 4$ & $147.38 \pm 4.56$ & $115.62 \pm 2.12$ & $17.31 \pm 1.12$ \\
\hline & F5 & $169.16 \pm 5.54$ & $131.81 \pm 2.0$ & $27.58 \pm 1.6$ \\
\hline \multicolumn{2}{|c|}{$\begin{array}{l}\text { Average } \\
\text { (range) }\end{array}$} & $\begin{array}{c}173.29 \\
(147.38-22,453)\end{array}$ & $\begin{array}{c}141.99 \\
(115.62-164.63)\end{array}$ & $\begin{array}{c}32.68 \\
(17.31-46.29)\end{array}$ \\
\hline \multirow{5}{*}{ Cooper } & $\mathrm{Cu} 1$ & $1.23 \pm 0.22$ & $0.34 \pm 0.02$ & $11.94 \pm .28$ \\
\hline & $\mathrm{Cu} 2$ & $3.26 \pm 0.56$ & $0.82 \pm 0.03$ & $45.82 \pm 1.78$ \\
\hline & $\mathrm{Cu} 3$ & $1.31 \pm 0.08$ & $0.98 \pm 0.04$ & $67.37 \pm 2.28$ \\
\hline & $\mathrm{Cu} 4$ & $5.58 \pm 0.42$ & $0.60 \pm 0.03$ & $16.37 \pm 0.16$ \\
\hline & $\mathrm{Cu} 5$ & $1.79 \pm 0.42$ & $0.26 \pm 0.02$ & $8.43 \pm 0.42$ \\
\hline \multicolumn{2}{|c|}{$\begin{array}{l}\text { Average } \\
\text { (RANGE) }\end{array}$} & $\begin{array}{c}2.63 \\
(1.23-5.58)\end{array}$ & $\begin{array}{c}0.60 \\
(0.26-0.98)\end{array}$ & $\begin{array}{c}29.99 \\
(8.43-67.37)\end{array}$ \\
\hline \multirow{5}{*}{ Aluminium } & Al1 & $2.76 \pm 0.76$ & $0.54 \pm 0.04$ & $23.36 \pm 1.14$ \\
\hline & $\mathrm{Al} 2$ & $1.56 \pm 0.17$ & $6.05 \pm 1.50$ & $36.99 \pm 1.61$ \\
\hline & $\mathrm{Al} 3$ & $3.08 \pm 0.61$ & $2.64 \pm 0.86$ & $27.91 \pm 1.31$ \\
\hline & Al4 & $7.24 \pm 0.73$ & $5,12 \pm 1.15$ & $55.49 \pm 2.29$ \\
\hline & Al5 & $5.23 \pm 0.74$ & $10.12 \pm 2.22$ & $64.58 \pm 2.65$ \\
\hline \multicolumn{2}{|c|}{$\begin{array}{l}\text { Average } \\
\text { (range) }\end{array}$} & $\begin{array}{c}3.97 \\
(1.56-7.24)\end{array}$ & $\begin{array}{c}4.89 \\
(0.54-10.12)\end{array}$ & $\begin{array}{c}41.67 \\
(23.36-64.580)\end{array}$ \\
\hline \multirow{5}{*}{ Wood } & Wo1 & $1.30 \pm 0.22$ & $0.27 \pm .03$ & $10.81 \pm .28$ \\
\hline & Wo2 & $10.75 \pm 2.31$ & $2.46 \pm 0.04$ & $7.79 \pm 0.41$ \\
\hline & Wo3 & $2.46 \pm 0.65$ & $3.51 \pm 1.33$ & $44.57 \pm 2.01$ \\
\hline & Wo4 & $5.56 \pm 0.92$ & $4.06 \pm 0.34$ & $72.26 \pm 3.13$ \\
\hline & Wo5 & $1.03 \pm 0.03$ & $5.25 \pm 0.58$ & $15.58 \pm 0.81$ \\
\hline \multicolumn{2}{|c|}{$\begin{array}{l}\text { Average } \\
\text { (range) }\end{array}$} & $\begin{array}{c}4.22 \\
(1.03-10.75)\end{array}$ & $\begin{array}{c}3.11 \\
(0.27-5.25)\end{array}$ & $\begin{array}{c}30.20 \\
(7.79-72.26)\end{array}$ \\
\hline
\end{tabular}

minerals, also iron scrap were used in high percentage [8]. For all the studied samples, the average values of $\mathrm{K}$ were lower than the world average values of 400 $\mathrm{Bq} / \mathrm{kg}$ [5]. Different concentrations of radioactive nuclei in the samples refer to the sources and environmental acting on these samples. The average activity concentrations of ${ }^{226} \mathrm{Ra},{ }^{232} \mathrm{Th}$ and ${ }^{40} \mathrm{~K}$ in the waste samples under study are given in Figure 1.

\subsection{Radiation Hazard from Waste Samples}

The calculated average values of radium equivalent activity $\left(\mathrm{R}_{\mathrm{eq}}\right)$, absorbed Gamma Dose Rate (D) and the Annual Effective Dose Equivalent $\left(D_{\text {eff }}\right)$, for all 
waste sample types and the total average values are shown in Table 2 . The radiological hazards were compared with the recommended values by UNSCEAR 2000. From this table, we can establish the following:

1) Radium equivalent activity $\left(R_{e q}\right)$

The minimum average value of $\mathrm{R}_{\mathrm{eq}}$ activity was $1.12 \mathrm{~Bq} \cdot \mathrm{Kg}^{-1}$ for Copper waste while the maximum average value was $378.86 \mathrm{~Bq} \cdot \mathrm{Kg}^{-1}$ for Iron waste, which is higher than the recommended maximum value of $370 \mathrm{~Bq} \cdot \mathrm{Kg}^{-1}$ [5]. The highest value in Iron is attributed to the high activity concentration level of ${ }^{226} \mathrm{Ra}$ and ${ }^{232} \mathrm{Th}$ in Iron waste samples. The total average value of $\mathrm{R}_{\mathrm{eq}}$ for all samples was 95.87 $\mathrm{Bq} \cdot \mathrm{Kg}^{-1}$, this value is lower than $370 \mathrm{~Bq} \cdot \mathrm{Kg}^{-1}$.

2) Absorbed gamma dose rate (D)

As shown in Table 2, the average value of the absorbed dose of all types of waste samples ranged from $2.79 \mathrm{nGyyh}^{-1}$ (Copper) to $163.86 \mathrm{nGyyh}^{-1}$ (Iron) with total average value $44.56 \mathrm{nGyyh}^{-1}$. UNSCEAR 2000 reported that the world wild average value in an air of outdoor absorbed dose $55 \mathrm{nGyh}^{-1}$ with at $\mathrm{y}$-pical range from 10 to $200 \mathrm{nGyh}^{-1}$. The average values for Copper, Aluminuim and Wood and the total average are lower than the recommended values by [5]. Table 2 shows that only for Iron waste samples, its absorbed average value is 3 times higher than the world average value. Figure 2 shows a comparison between the

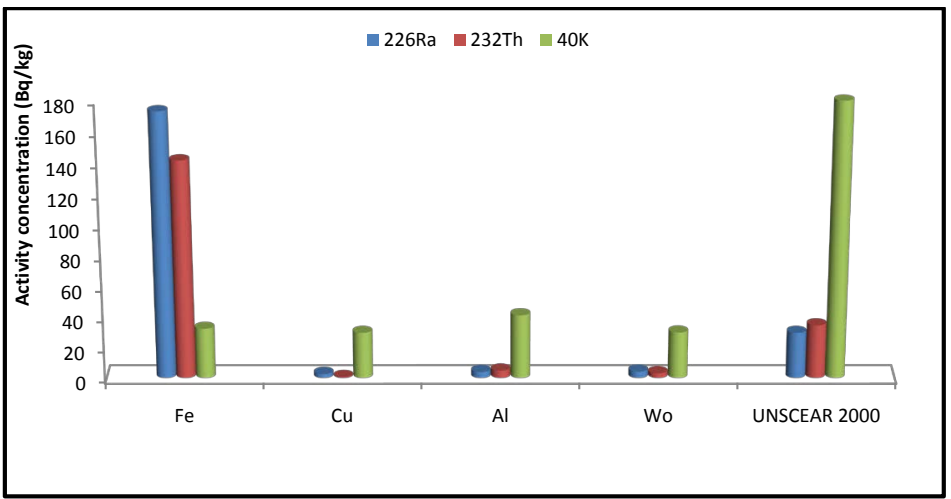

Figure 1. Average activity concentrations of ${ }^{226} \mathrm{Ra},{ }^{232} \mathrm{Th}$ and ${ }^{40} \mathrm{~K}$ for waste samples collected from different Industrial workshops, Saudi Arabia

Table 2. Comparison of the average radiological hazard of the studied waste samples.

\begin{tabular}{cccccc}
\hline Sample no. & $\begin{array}{c}\text { Radium } \\
\text { equivalent } \\
\text { activity } \\
\left(\mathrm{Bq} / \mathrm{kg}^{-1}\right)\end{array}$ & $\begin{array}{c}\text { Absorbed } \\
\text { dose }\left(\mathrm{nGyh}^{-1}\right)\end{array}$ & $\begin{array}{c}\text { Deff (indoor) } \\
(\mathrm{mSv} / \mathrm{y})\end{array}$ & $\begin{array}{c}\text { Deff } \\
(\text { outdoor }) \\
(\mathrm{mSv} / \mathrm{y})\end{array}$ & $\begin{array}{c}\text { Excess lifetime } \\
\text { cancer risk } \\
\text { outdoors } \\
(\mathrm{CR}) \times 10^{-3}\end{array}$ \\
\hline Iron & 378.86 & 163.86 & 0.73 & 0.18 & 2.54 \\
Copper & 1.12 & 2.79 & 0.012 & 0.003 & 0.04 \\
Aluminium & 1.70 & 6.54 & 0.029 & 0.007 & 0.10 \\
Wood & 1.80 & 5.04 & 0.022 & 0.006 & 0.08 \\
Range of average & $1.12-378.86$ & $2.79-163.86$ & $0.012-0.73$ & $0.003-0.18$ & $0.04-2.54$ \\
Total average & 95.87 & 44.56 & 0.20 & 0.05 & 0.69 \\
UNSCEAR & $<370$ & 60 & 0.42 & 0.07 & 0.29 \\
2000 & & & & & \\
\hline
\end{tabular}




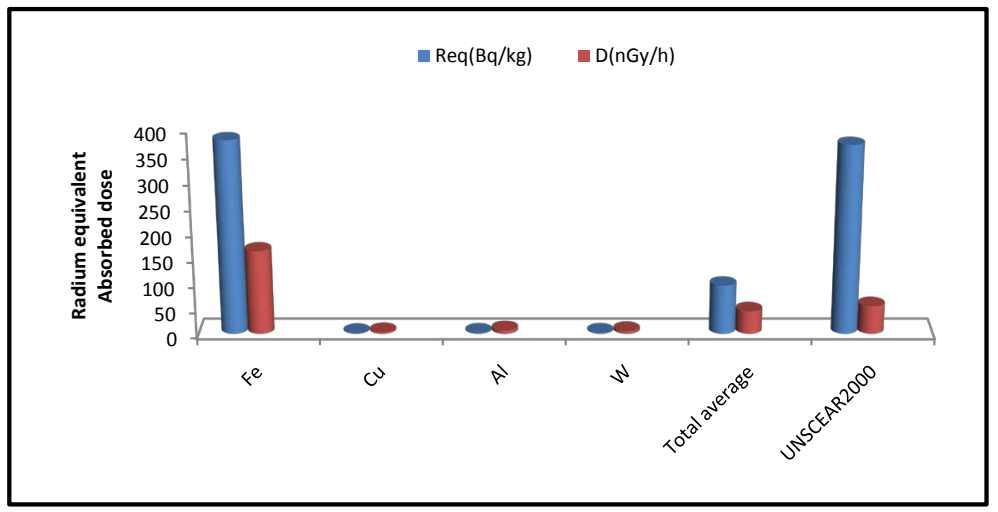

Figure 2. Comparing the average and the total average values of absorbed dose rate (nGy/h), and Radium equivalent (Bq/Kg) of the waste samples with UNSCEAR 2000.

average and total average values of radium equivalent (in $\mathrm{Bq} \cdot \mathrm{Kg}$ ) and absorbed dose (in $\mathrm{nGyyh}^{-1}$ ) for the waste samples under investigation and the recommended values by UNSCEAR 2000.

3) The annual effective dose equivalent

The average annual effective dose of indoor and outdoor for all samples ranged from $0.012 \mathrm{mSvy}^{-1}$ (Copper) to $0.73 \mathrm{mSvy}^{-1}$ (Iron) and from 0.003 $\mathrm{mSvy}^{-1}$ (Copper) to $0.18 \mathrm{mSvy}^{-1}$ (Iron) with the corresponding total average values of $0.20 \mathrm{mSvy}^{-1}$ and $0.05 \mathrm{mSvy}^{-1}$, respectively. These average values are less than the world average annual effective dose indoor $0.42 \mathrm{mSvy}^{-1}$ and outdoor $0.07 \mathrm{mSvy}^{-1}$ as reported by [5]. The maximum average values for outdoor and indoor effective doses were observed in Iron are higher than the world average effective dose for outdoor and indoor. This indicates that there is a significant effect for the workers in Iron workshops.

4) Excess lifetime cancer risk (ELCR)

The average values of ELCR ranged from $0.04 \times 10^{-3}$ in Copper to $2.54 \times 10^{-3}$ in Iron, with a total average value of $0.69 \times 10^{-3}$. The average values of ELCR for all waste types are less than the world average $\left(0.29 \times 10^{-3}\right)$ reported by [5]. The ELCR for Iron exceeded this value; this indicates that there is no risk to the general public and the workers in the industrial workshops which produce wastes of Copper, Aluminium and Woods and the workplace are still in zone of normal radiation, but there is a threat to the workers' health in Iron workshops.

\section{Conclusion}

The activities of the natural radionuclides ${ }^{238} \mathrm{U},{ }^{226} \mathrm{Ra},{ }^{232} \mathrm{Th}$ and ${ }^{40} \mathrm{~K}$ in the solid waste samples collected from various industrial workshops in Saudi Arabia were measured by using a gamma-ray spectroscopy with HPGe detector. The total average values of radium equivalent, external hazard, absorbed dose and effective dose of all studied samples are below the internationally accepted values. The measured samples are still in the zones of normal radiation level, causing no threat to the environment, the human health, and the workers at the workshops except the Iron waste may create some radiological complications. The results may be useful in the assessment of the exposures and the radiation doses due to 
the natural radioactive content in industrial solid waste samples. They may provide a wide serve as a guideline for future measurement and assessment of possible radiological risks to human health.

\section{Recommendation}

We recommend two major steps to be taken into account: first, reducing the hours of operation at the workshops of iron; second, using ventilation and respirators in the workplace at all industrial workshops. Finally, there must be the radiological control on the operation of such industrial workshops.

\section{References}

[1] Żak, A., et al. (2010) Natural Radioactivity of Wastes. Nukleonika, 55, 387-391.

[2] Alamoudi, Z.M. (2013) A Study of Natural Radioactivity in the Welding Workshops Waste. Journal of American Science, 6, 400-405.

[3] ALamoudi, Z.M. and ALmehmadi, F.G. (2013) Concentrations of the Naturally Occurring Radioactive Materials in Waste Samples from Iron Production, the Carbon Filters Used in Saudi Arabia. Life Science Journal, 10, 641-647.

[4] El-Taher, A. (2015) Radioactivity Measurements and Radiation Dose Assessments in Soil of Al-Qassim Region, Saudi Arabia. Indian Journal of Pure \& Applied Physics (IJPAP), 52, 147-154.

[5] UNSCEAR (2000) Report to the General Assembly, Vol. I. Sources and Effects of Ionizing Radiation. United Nations, New York.

[6] Beretka, J. and Mathew, P. (1985) Natural Radioactivity of Australian Building Materials, Industrial Wastes and By-Products. Health Physics, 48, 87-95. https://doi.org/10.1097/00004032-198501000-00007

[7] ICRP (1990) Recommendations of ICRP, Publication 60. In: ICRP, Ed., Pergamon Press, Oxford.

[8] Ibrahiem, N.A., et al. (2000) Concentrations in Cool and Its End Product in Steel Production. IRPA in the 10th International Radiation Protection Association, IRPA, 4-19.

\section{Submit or recommend next manuscript to SCIRP and we will provide best service for you:}

Accepting pre-submission inquiries through Email, Facebook, LinkedIn, Twitter, etc. A wide selection of journals (inclusive of 9 subjects, more than 200 journals) Providing 24-hour high-quality service User-friendly online submission system Fair and swift peer-review system Efficient typesetting and proofreading procedure Display of the result of downloads and visits, as well as the number of cited articles Maximum dissemination of your research work

Submit your manuscript at: http://papersubmission.scirp.org/

Or contact gep@scirp.org 